\title{
Brand Extensions: A Qualitative Meta-Analysis Of 20 Years Of Marketing Research
}

Elise Prosser, Ph.D. (Email: eprosser@sandiego.edu), University of San Diego

Melissa St. James (Email: mstjames@tidalwave.net), California State University - San Bernardino

\begin{abstract}
Brand extensions, or new product introductions under an existing brand name, have become increasingly popular over the past 20 years. Marketers tout brand extensions as enjoying higher market share and profitability than launching new brand names that require exorbitant advertising expenditures (Smith \& Park 1992). According to some estimates, brand extensions account for more than $90 \%$ of new product introductions in some categories (Volckner \& Sattler 2002). However, one study found that $27 \%$ of line extensions failed (Reddy, et al 1994). Furthermore, excessively stretching the brand to various products may risk brand dilution. A brand extension failure is seen as harming the parent brand. The authors provide a qualitative meta-analysis that summarizes sixty-three articles comprising the brand extension research over the past twenty years (1981-2000). They suggest three propositions that represent three major conclusions reached by the studies and present evidence of support for each.
\end{abstract}

\section{Introduction \& Methodology}

The following parable describes the past twenty years of brand extension research:

Two blind men feel an elephant at opposite ends. When asked what an elephant is, the first man replies: "A long thin trunk." When asked what an elephant is, the second man replies: "A long thin tail." The two blind men basically agree on the shape of the elephant, but miss the body in between.

Adapted from Wells (1993)

This parable appropriately describes the evolution of the cumulative knowledge within the brand extension literature. There have been two major approaches taken to examine "the nature of the beast." The first is a marketing strategy and modeling approach. The second is a consumer behavior and information-processing perspective. The objective of this paper is to present a qualitative meta-analysis of the marketing literature on brand extensions: sixtythree articles published over 20 years (1981-2000) cited on www.umi.com/proquest. Pre-database publications were found by tracking references of earliest articles. Prominent marketing journals that published research on brand extensions include: Journal of Marketing Research, Journal of Marketing, Journal of Consumer Research, Marketing Science, Journal of Advertising Research, Journal of Product and Brand Management, among others. See references for a complete list.

The paper is organized as follows. First, a description of qualitative meta-analysis is offered. Second, the articles are categorized terms of the two approaches. Propositions that arise from the brand extension research are developed. Third, support for the propositions and variation among studies is discussed. Finally, opportunities for future research are outlined. 


\section{Qualitative Meta-Analysis}

The "meta-analysis" technique has been employed by researchers to build generalizations from many individual studies (e.g., advertising elasticity by Assmus, et al. 1984; price elasticity by Tellis 1988; customer satisfaction by Szymanski \& Henard 2001). A meta-analysis treats each separate study as a data point in an imperfect replication experiment and uses ANOVA to identify sources of variation that may differentiate systematic effects of particular study characteristics. Adjustment for those effects allows generalization about the common elements in the studies (Assmus, et al. 1984).

Quantitative meta-analysis requires a large enough sample of studies that measure the same construct in order for the average of each measure to be statistically valid. Meta-analysis provides a mean estimate for each measure and explains its variation by inter-study differences. "Meta-analysis is a systematic, objective, efficient and precise way of summarizing past results, but does not provide a final statement of truth on the issue" (Tellis 1988, p. 331).

A "qualitative meta-analysis" also seeks to build generalizations on important topics that have spurred many individual studies. However, a qualitative meta-analysis is used when there are not enough common quantitative measures to statistically support averaging across studies (Pechmann \& Stewart 1994). Furthermore, qualitative metaanalysis is appropriate when many studies utilize different methodologies and measures to study the same phenomenon. One of the primary objectives of science is the production of generalizations by synthesizing studies (Ryan and Barclay 1983). Furthermore, Lehmann (1996) advocates qualitative meta-analysis:

"The purpose of academic research is to ... perform meta-analysis... While generally thought of as a technique for summarizing of quantitative results, the basic thought process of meta-analysis applies to qualitative work as well. Any single study, no matter how well executed, has an infinite number of covariates that could potentially explain the results. By contrast, generalizations can emerge only from a collection of studies."

The rich history of brand extension research warrants a qualitative meta-analysis. The earliest article that specifically addressed brand extensions quietly appeared in 1981 (Tauber). The article took note of firms' increasing use of brand extensions and implored academicians and practitioners to investigate further the benefits and drawbacks of brand extensions. Unfortunately, no articles were published. Four years, later, Tauber (1985) categorized several types of brand extensions and again called for more research on brand extensions. Again, no articles were published. In 1988, Tauber pointed out that over $40 \%$ of new products introduced in the prior two decades had been brand extensions. Despite the prevalence of practitioners' use of brand extensions, academic research lagged behind. In the 1980's, only a handful of articles addressing the brand extension phenomenon were published. By contrast, during the 1990's, 55 articles were produced in the marketing literature. This paper presents a qualitative meta-analysis summarizing the two major methodological approaches in the 64 articles that comprise the brand extension literature. The first is a marketing strategy approach. The second is a consumer behavior approach. Propositions and support are discussed, and managerial implications are suggested.

\section{Marketing Strategy Approach}

The marketing strategy approach analyzes the transfer of brand equity to and from brand extensions and the advantages and disadvantages of utilizing brand extensions as an effective strategy for firms. Early interest in brand extensions arose in the mergers and acquisitions heyday of the 1980's. As Procter \& Gamble acquired RichardsonVicks, Philip Morris consumed General Foods and R. J. Reynolds took over Nabisco, almost $\$ 15$ billion was paid for about 400 brand names (Tauber 1988). More than a decade later, Capron \& Hulland (1999) confirm that brand extensions are most likely to be redeployed after horizontal acquisitions.

Brand extensions were supposed to be the big payoff for the premium prices paid for brands in the corporate takeovers. They represented a way to capitalize on existing brand names by efficiently introducing new products. 
Transferring the brand equity of well-known brands to extensions in other product categories was a strategic opportunity for firms to enter new markets with less cost and less risk (Tauber 1981, 1985). Hence, the following aggregate proposition has been advanced:

$\mathrm{P}_{1}$ : $\quad$ Brand extensions are efficient and effective ways to capitalize on the brand image and equity a firm already owns.

However, along with any reward goes risk. If successful extensions benefit from the transfer of positive equity from the parent brand, certainly there must be risk of a failed extension harming and/or diluting the equity of the parent brand. Hence, the following counter-proposition has also been advanced:

$\mathrm{P}_{2}$ : $\quad$ Brand extensions may dilute or harm the family brand equity if unsuccessful or too numerous.

\section{Support for Marketing Strategy Propositions}

There is ample support for $\mathrm{P}_{1}$. Brand extensions have been shown to capture an average of 8.3 more market share points and advertising ratios of 8.7 percentage points lower than those of new brands (Smith \& Park 1992). High market share and high priced brands tend to aggressively expand their product lines ( Putsis \& Bayus 2001). A study of 107 brand across 41 product categories with 4,380 respondents found that brand trust and affect combine to determine purchase loyalty, which leads to greater market share (Chaudhuri \& Holbrook 2001). Even the stock market will react favorably to a brand extension announcement if attitude and familiarity are positive (Lane \& Jacobson 1995).

The transfer of equity from the parent brand to the extension facilitates awareness and trial (Aaker \& Keller 1990; Keller 1993; Aaker \& Joachimsthaler 2000; Tauber 1981, 1988; Park, et al 1986; Reddy, et al 1994). There is less risk of cannibalization from brand extensions vs. line extensions because the firm is entering new markets instead of offering variant within the same product line (Romeo 1991; Sullivan 1988; Tauber 1988). Furthermore, successful brand extensions were found to increase a brand's survival time by almost thirty years (Sullivan 1992). The broader the "brand architecture," the further the brand can be extended ( Aaker \& Joachimsthaler 2000). Consumers may even be willing to pay a premium for a trusted brand (Blackston 1995).

With all these potential benefits, there must also exist potential risks. Accordingly, almost all papers on brand extensions mention the risk of harming or diluting the family brand equity. Extensions are thought to be detrimental when the sharp focus of the brand image becomes blurred in consumers' minds. The more products under a brand name, the argument proposes, the less meaning the brand name has (Ries \& Trout 1981). Furthermore, should an extension fail, the family brand image may be irreparably harmed, particularly when the extension is in a category close to the original product category (Romeo 1991). The transfer of negative equity has reciprocal effects not only from the parent to the extension, but also from the extension to the parent (Aaker \& Keller 1994; Farquhar 1994). High equity brands are particularly vulnerable. Brand equity can also be diluted by retailer display decisions (Buchanan, et al 1999).

Cohen, et al (1997) warn that introducing too many new products may result in a low success rate. They analyzed 51 new product launches over a three-year period at a major food manufacturer. Their findings underscore the need for firms to invest in total labor hours on prototype development and testing and to put an experienced R\&D champion on the project. Analyzing scanner panel data, Erdem (1998) found that consumers who are uncertain about quality might rely upon the signaling theory of "umbrella branding." Boad (1999) describes common pitfalls that may arise from co-branding and Park, Jun \& Shocker (1996) test effects of a "modifier" brand complementing "header" (main) brand. Cross-brand cannibalization is also a serious threat (Harvey, et al 1998). Brands that have suffered negative equity must be revitalized as soon as possible or the asset will be lost (Keller 1999). Negative thoughts about inconsistent extensions decrease as repeated exposure rises, (Lane 2000), making revitalization possible.

While $\mathrm{P}_{1}$ and $\mathrm{P}_{2}$ may appear to be opposite propositions, they may both be true under certain conditions. For example, the effect of brand extensions may rely on the type of brand image. Prestigious brands appear to stretch further 
than functional brands (Park, et al. 1991). High quality brands seem to have more resilience after a failed brand extension (Keller \& Aaker 1992). Sixty percent of firms surveyed indicated the brand name alone (without advertising or sales promotion) can influence sales (Kohli \& La Bahn 1997). Furthermore, brand value depends on the consumer's perspective (Crimmons 2000). Strong credible brands develop "brand waves" that gain consumers' consideration and loyalty (Farquhar 1994; 2000). Likewise, "brand alliances" represent a symbiosis of reputation endorsement (Cooke \& Ryan 2000) where consumer attitudes depend on product and brand fit (Simonin \& Ruth 1998). Consumers rely on information about the parent brand to make inferences about extensions (Sullivan 1998).

Secondly, the effect of brand extensions may be moderated by the position of the brand in its life cycle as well as the position of the extension in its product category life cycle. In a longitudinal cross-category study, it was found that brand extensions outperformed new-name brands when introduced middle-to-late in the life cycle (Sullivan 1992). Introducing a brand extension after a market pioneer has established the category may be a successful strategy (Golder \& Tellis 1993).

Finally, the sequence of introduction may help determine the effect of brand extensions. Most studies examined only a single initial brand extension. Multiple intervening extensions may have cumulative effects. After an unsuccessful extension that was perhaps too "far" from the core products, a firm can retrench and introduce several other "closer" extensions over time (Keller \& Aaker 1992). The use of "hierarchical categorization" (Oakenfull, et al 2000) may help managers identify which brand extensions into related categories (Park \& Srinivasan 1994) are acceptable to consumers.

It is difficult to resolve the conflict between $\mathrm{P}_{1}$ and $\mathrm{P}_{2}$. The various effects of brand extensions described in extant articles are affected by the specific conditions under which each study was conducted. Furthermore, the transfer of brand equity is inherently an intangible phenomenon that is difficult to quantify and operationalize. Whether a brand extension has been a success or failure for a firm is ambiguous; much of the support for $\mathrm{P}_{2}$ is anecdotal, described after many years' hindsight. Therefore, the net result of the advantages and disadvantages of brand extensions is still somewhat inconclusive. Additional studies building upon the particular conditions listed above would contribute to the advancement of knowledge on brand extensions from a marketing strategy perspective.

\section{Consumer Behavior Proposition}

The second major approach to the study of brand extensions has been from the consumer behavior perspective that utilized information-processing theories from psychology. Categorization theory and schema congruence provide the foundation for consumer similarity judgments. Categorization theory suggests that positive or negative affect is transferred from the family brand image to the extension as consumers evaluate how "typical" the extension is of the category (Loken \& Roedder-John 1993).

Schema congruence suggests that knowledge is organized around a "schema," or some concept meaningful to the consumer. Brand names serve as "cues" which may offer expert source credibility to aid consumer evaluations (Boush \& Loken 1991). Similarity between the family brand image and the extension seems to play an important role. Hence, the following aggregate proposition has been advanced in numerous studies:

$\mathrm{P}_{3}$ : $\quad$ Consumers evaluate brand extensions by comparing the "similarity" or "perceived fit" between the family brand image and the extension.

\section{Support for Consumer Behavior Proposition}

There is strong support for $\mathrm{P}_{3}$. It has been shown that consumers base evaluations of an extension on the similarity to the family brand image. Several "factors of similarity" have been proposed by various studies. Product category similarity has been shown to affect consumer judgments. While one study found a positive linear relationship: 
the greater the product similarity of the new product to the existing product, the greater the transfer of positive or negative affect to that product (University of Minnesota Consumer Behavior Seminar 1987), another study found an inverted U relationship: products that are moderately congruent gain the most favorable evaluations (Meyers-Levy \& Tybout 1989).

There are a variety of factors affecting consumer evaluations of brand extensions. Factors related to the extension such as salience of physical features, benefits, or usage (Chakravarti, et al 1990), functional vs. prestige brand (Park, et al 1991), even assumed manufacturing expertise of the parent brand were found to influence evaluations of the extension (Aaker \& Keller 1990). Perceived fit increases as the amount of information and exposure increase (Klink \& Smith 2001; Kardes \& Allen 1991). Exposure to advertising of the extension increases parent brand recognition and recall (Morrin 1999), but trademark-diluting advertisements will result in brand recognition errors (Morrin \& Jacoby 2000). Advertising with a complementary ally highlighting product differentiation results in favorable attitude (Samu, et al 1999). Signaling unobservable product quality through a credible brand ally can also increase quality perceptions (Rao, et al 1999). If the extension fails, both the parent brand and flagship brand can be negatively impacted and diluted (Roedder-John, et al 1998).

Factors related to consumers such as consumer mood (Barone, et al 2000), motivation (Gurhan-Canli \& Maheswaran 1998), ownership status (Kirmani et al 1999), and accessibility of the extension information (Ahluwalia \& Gurhan-Canli 2000) were also found to moderate brand evaluations. Encouraging consumers to establish explanatory links connecting the parent and extension increases perceived fit (Bridges, et al 2000). For example, social responsibility of the parent brand may influence consumer acceptance of an extension (Dacin \& Brown 1997).

While there appears to be strong support for $\mathrm{P}_{3}$, the relative magnitude of the effects differs across studies, depending on the specific conditions and experimental stimuli manipulated. For example, product similarity effects were stronger for studies that used hypothetical brands (University of Minnesota Consumer Behavior Seminar 1987) than for studies that used real brands (Aaker \& Keller 1992; MacInnis et al 1992; Smith \& Park 1992). With real brands, the presence of experts and novices among subjects may have affected evaluations (Muthukrishnan \& Weitz 1991). When product knowledge was high, brand specific associations dominated affect and category similarity (Broniarczyk \& Alba 1994).

Secondly, the specific definitions of "fit" and "similarity" may explain some variance in the studies. MacInnis et al (1992) differentiated between similarity and fit and showed that similarity plays three roles in affecting evaluation judgments: indirectly through a direct effect on fit, indirectly through an indirect effect on fit and directly. Brand affect and "symbolic idealness" were also separated as two constructs. Symbolic idealness enhances the desirability of attributes and is not necessarily dependent on similarity. In previous studies, fit had been defined more broadly as "when the consumer accepts the extension as logical" (Tauber 1988), as "explanatory likeness" (Bridges 1992), or as complementarity, substitutability, and manufacturing expertise (Aaker \& Keller 1990).

Thirdly, the "distance" between the brand extension and the core product may explain variance. Certain studies considered very "close" extensions, some of which may be considered line extensions (new products within the same category) instead of brand extensions (new products introduced into a new category) (Roedder-John et al 1998; Ries \& Trout 1981; Romeo 1991; Sullivan 1998). Some studies considered very "far" extensions such as McDonald's photo processing (Aaker \& Keller 1990) and Marlboro orange juice (Herr, et al. 1993) to determine the bounds of extendibility. Yet other studies considered a gradient (Boush \& Loken 1991; Farquhar 1994; Keller \& Aaker 1992; Meyers-Levy \& Tybout 1989; Oakenfull, et al 2000; Park \& Srinivasan 1994).

Finally, brands and their extensions do not live in isolation; each product category has various competitors. In addition to distance between product categories, variation among brands within a category influence similarity judgments (Yoo, et al 2000). Furthermore, variation among a brand's current product line, or "brand breadth" affects how favorably consumers view the extension (Bousch \& Loken 1991). The more products affiliated with a brand, the stronger the favorability of consumers' evaluations of extension quality, when portfolio variance was low (Dacin \& Smith 1994). Despite several sources of variance across studies, a dominant approach to the study of consumer 
evaluations of brand extensions has emerged based on experimental manipulations of similarity. One study found that the factors of similarity explained between $60 \%$ and $75 \%$ of the variation in evaluation judgments (MacInnis, et al 1992).

Further research using other paradigms that do not specify dimensions of similarity may augment the literature. Other techniques such as Repertory Grid (Neimeyer, et al. 1990) and Metaphor Elicitation Technique (Coulter \& Zaltman 1994; Catchings-Castello 2000) elicit rather than manipulate the constructs by which consumers evaluate brand extensions, augmenting verbal with visual (non-verbal) stimuli for hidden meanings when appropriate (Supphellen 2000). Different research techniques (such as free association, brand personality, brand symbols and brand personification) vary in their ability to capture alternate dimensions of brand image, purchase intent and product usage frequency (Roth 1994). These techniques may advance our understanding of how consumers evaluate brand extensions.

\section{Summary and Conclusions}

A summary of the 63 articles comprising the brand extension literature (1981-2000) and the perspective of each (marketing strategy vs. consumer behavior) is provided in Table 1. Articles that focused solely on marketing strategy such as a conceptual framework of think piece will show a check under the "MS" column. Articles that employed a consumer behavior approach with experimental manipulations will show a check under the "CB" column. Several articles combined both approaches. These will have a check under both columns. Where do we go from here? Like the two blind men feeling their ways around an elephant, each participant must reach toward the middle so that the true nature of the "beast" is revealed.

\section{References}

1. Aaker, David A. and Erich Joachimsthaler (2000), "The brand relationship spectrum: The key to the brand architecture challenge", California Management Review, 42:4, 8-24.

2. _ _ and Kevin L. Keller (1990), "Consumer Evaluations of Brand Extensions", Journal of Marketing, 54 (January), 27-41.

3. Ahluwalia, Rohini and Zeynep Gurhan-Canli (2000), "The effects of extensions on the family brand name: An accessibility-diagnosticity perspective", Journal of Consumer Research, 27:3, 371-382.

4. Ambler, Tim and Chris Styles (1997), "Brand Development versus New Product Development: Towards a Process Model of Extension Decisions" Journal of Product and Brand Management, 6:1, 13-26.

5. Assmus, Gert, John U. Farley, and Donald R. Lehmann (1984), "How Advertising Affects Sales: MetaAnalysis of Econometric Results", Journal of Marketing Research, 21 (February), 65-74.

6. Barone, Michael J., Paul W. Miniard and Jean B. Romeo (2000), "The influence of positive mood on brand extension evaluations", Journal of Consumer Research, 26:4, 386-401.

7. Blackston, Max (1995), "The qualitative dimension of brand equity", Journal of Advertising Research, 35:4, RC-6.

8. Boad, Bob (1999), “Co-branding comes of age”, Managing Intellectual Property, 94, 20.

9. Boush, David M. and Barbara Loken (1991), "A Process-Tracing Study of Brand Extension Evaluation", Journal of Marketing Research, 28 (February), 16-28.

10. Bragg, Arthur (1986), "Back to the Future", Sales and Marketing Management. 137(Nov) 61-62.

11. Bridges, Sheri (1992), "A Schema Unification Model of Brand Extensions", Marketing Science Institute Works Paper, Reprint \#92-123 (August).

12. Levin Lane Keller, and Sanjay Sood (2000), "Communication strategies for brand extensions: Enhancing perceived fit by establishing explanatory links", Journal of Advertising, 29:4, 1-11.

13. Broniarczyk, Susan M. and Joseph W. Alba (1994), "The importance of the brand in brand extension", Journal Of Marketing Research, 31:2, 214-229.

14. Buchanan, Lauranne, Carolyn J. Simmons and Barbara A. Bickart (1999), "Brand equity dilution: Retailer display and context brand effects”, Journal of Marketing Research, 36:3, 345-356. 
15. Capron, Laurence and John Hulland (1999), "Redeployment of brands, sales forces, and general marketing management expertise following horizontal acquisitions: A resource-based view", Journal of Marketing, 63:2, 41-55.

16. Catchings-Castello, Gwendolyn (2000), “The ZMET alternative”, Marketing Research, 12:2 , 6-13.

17. Chakravarti, Dipankar, Deborah J. MacInnis, and Kent Nakamoto (1990), "Product Category Perceptions, Elaborative Processing and Brand Name Extension Strategies", in Advances in Consumer Research, 17, 910-916.

18. Chaudhuri, Arjun and Morris B Holbrook (2001), "The chain of effects from brand trust and brand affect to brand performance: The role of brand loyalty", Journal of Marketing, 65:2, 81-94.

19. Cohen, Morris A., Jehoshua Eliashberg, and Teck H. Ho (1997), “An anatomy of a decision-support system for developing and launching line extensions", Journal of Marketing Research, 34:1, 117-130.

20. Cooke, Sinead and Paul Ryan (2000), "Brand alliances: From reputation endorsement to collaboration on core competencies", Irish Marketing Review, 13:2, 36-42.

21. Coulter, Robin Higie, and Gerald Zaltman (1994), "Using the Zaltman Metaphor Elicitation Technique to Understand Brand Images", Advances in Consumer Research, 21, 501-507.

22. Crimmins, James C. (2000), "Better measurement and management of brand value", Journal of Advertising Research, 40: 6, 136-145.

23. Dacin, Peter A. and Tom J. Brown. (1997), "The company and the product: Corporate associations and consumer product responses", Journal of Marketing, 61:1, 68-85.

24. and Daniel C. Smith (1994), "The effect of brand portfolio characteristics on consumer", Journal of Marketing Research, 31:2, 229-243.

25. The Economist (1990), "Brand-Stretching can Be Fun - and Dangerous", (May 5), 77-80.

26. Erdem, Tulin (1998), “An empirical analysis of umbrella branding”, Journal of Marketing Research, 35:3, 339-352.

27. Farquhar, Peter H. (1994), "Strategic challenges for branding", Marketing Management, 3:2, 8-16.

28. (2000), "Brand waves: Building momentum throughout the ownership cycle", Marketing Management, 9:2, 14-22.

29. Golder, Peter and Gerard Tellis (1993), “Pioneer Advantage Marketing Legend or Marketing Logic?” Journal of Marketing Research, 30 (May), 158-170.

30. Gurhan-Canli, Zeynep and Durairaj Maheswaran (1998), "The effects of extensions on brand name dilution and enhancement", Journal of Marketing Research, 35:4, 464-474.

31. Harvey, Michael, James T. Rothe and Laurie A. Lucas (1998), "The "trade dress" controversy: A case of strategic cross-brand cannibalization", Journal of Marketing Theory and Practice, 6:2, 1-15.

32. Herr, Paul M., Peter H. Farquhar, and Russell H. Fazio (1993), "Using Dominance Measures to Evaluate Brand Extensions", working paper, Marketing Science Institute, Report Number 93-120, (November).

33. Kardes, Frank R. and Chris T. Allen (1991), "Perceived Variability and Inferences about Brand Extensions", Advances in Consumer Research, 18, 392-8.

34. Keller, Kevin Lane (1993), "Conceptualizing, measuring, and managing customer-based brand equity", Journal of Marketing, 57:1, 1-22.

35. (1999), "Managing brands for the long run: Brand reinforcement and revitalization strategies", California Management Review, 41:3, 102-125.

36. and David A. Aaker (1992), "The Effects of Sequential Introduction of Brand Extensions", Journal of Marketing Research, 29 (February), 35-50.

37. Kirmani, Amna, Sanjay Sood, and Sheri Bridges (1999), "The ownership effect in consumer responses to brand line stretches", Journal of Marketing, 63:1, 88-104.

38. Klink, Richard R. and Daniel C. Smith (2001), "Threats to the external validity of brand extension research", Journal of Marketing Research,38:3, 326-335.

39. Kohli, Chiranjeev and Douglas W. LaBahn (1997), "Observations: Creating effective brand names: A study of naming process", Journal of Advertising Research, 37:1, 67-76.

40. Lane, Vicki R. (2000), "The impact of ad repetition and ad content on consumer perceptions of incongruent extensions", Journal of Marketing, 64:2, 80-92. 
41. _ and Robert Jacobson (1995), "Stock market reactions to brand extension announcements", Journal of Marketing, 59:1, 63-78.

42. Lehmann, Donald R. (1996), "Knowledge generalization and the conventions of consumer research: A study in inconsistency", Advances in Consumer Research, Vol. 23.

43. Loken, Barbara and Deborah Roedder-John (1993), "Diluting brand beliefs: When do brand extensions have a negative impact?" Journal of Marketing, 57:3, 71-85.

44. MacInnis, Deborah J., Kent Nakamoto, and Gayathri Mani (1992), "Cognitive Associations and Product Category Comparisons: The Role of Knowledge Structure and Context”, Advances in Consumer Research, vol. 19, 260-267.

45. Meyers-Levy, Joan and Alice M. Tybout (1989) "Schema Congruity as a Basis for Product Evaluation", Journal of Consumer Research, 16 (1), 39-54.

46. Morrin, Maureen (1999), "The impact of brand extensions on parent brand memory structures and retrieval processes", Journal of Marketing Research, 36:4, 517-526.

47. $\quad$ and Jacob Jacoby (2000), "Trademark dilution: Empirical measures for an elusive concept", Journal of Public Policy \& Marketing, 19:2, 265-277.

48. Muthukrishnan and Barton Weitz (1991) "The Role of Product Knowledge in the Evaluation of Brand Extensions", Advances in Consumer Research, 18, 407-13.

49. Neimeyer, Robert A. Kurt D. Baker, and Greg J. Neimeyer (1990), "Analytic Issues in the Use of Repertory Grid Techniques", Advances in Personal Construct Psychology, Volume 1, 25-48.

50. Oakenfull, Gillian, Edward Blair, Betsy Gelb and Peter Dacin (2000), "Measuring brand meaning", Journal of Advertising Research, 40:5, 43-54.

51. Park, Chan Su and V. Srinivasan (1994), "A survey-based method for measuring and understanding brand", Journal of Marketing Research, 31:2, 271-289.

52. Park, Whan C., Bernard Jaworski, and Deborah J. MacInnis (1986), "Strategic Brand Concept: Image Management", Journal of Marketing, 50, 135-145.

53. Lung Youl Jun and Allan D. Shocker (1996), "Composite branding alliances: An investigation of extension and feedback effects", Journal of Marketing Research, 33:4, 453-567.

54. _ _ Sandra Milberg, and Robert Lawson (1991), "Evaluation of Brand Extensions: The Role of Product Feature Similarity and Brand Concept Consistency", Journal of Consumer Research, 18 (September), 185-193.

55. Pechmann, Cornelia and David W. Stewart (1994), "The Psychology of Comparative Advertising", in E. Clark, T. Brock, and D. W. Stewart (Eds.), Attention, Attitude, and Affect in Response to Advertising, Hillsdale, NJ: Erlbaum, 79-96.

56. Putsis, William P. Jr. and Barry L. Bayus (2001), "An empirical analysis of firms' product line decisions", Journal of Marketing Research, 38:1, 110-119.

57. Rao, Akshay R., Lu Qu and Robert W. Ruekert (1999), "Signaling unobservable product quality through a brand ally", Journal of Marketing Research, 36:2, 258-269.

58. Reddy, Srinivas, Susan L. Holak and Subodh Bhat (1994), "To extend or not to extend: success determinants of brand line extensions", Journal of Marketing Research, 31(May), 243-262.

59. Ries, Al and Jack Trout (1981), "Positioning: The Battle for Your Mind", New York, NY: McGraw-Hill.

60. Roedder-John, Deborah, Barbara Loken and Christopher Joiner (1998), "The negative impact of extensions: Can flagship products be diluted?" Journal of Marketing, 62:1, 19-33.

61. Romeo, Jean (1991), "The Effect of Negative Information on the Evaluation of Brand Extensions and the Family Brand", Advances in Consumer Research, 18, 399-406.

62. Roth, Martin (1994), "Innovations in Defining \& Measuring Brand Image", Advances in Consumer Research, Vol. 21, 495.

63. Ryan, Michael J. and Donald W. Barclay (1983), "Integrating Results from Independent Studies", Advances in Consumer Research, Vol. X, The Association for Consumer Research, 492-496.

64. Samu, Sridhar, H. Shanker Krishnan and Robert E. Smith (1999), Using advertising alliances for new product introduction: Interactions between product complementarity and promotional strategies, Journal of Marketing, $63: 1,57-75$. 
65. Simonin, Bernard 1. and Julie A. Ruth (1998), Is a company known by the company it keeps? Assessing the spillover effects of brand alliances on consumer brand attitudes, Journal of Marketing Research, 35:1, 30-43.

66. Smith, Daniel C. and Whan C. Park (1992), "The Effects of Brand Extensions on Market Share and Advertising Efficiency", Journal of Marketing Research,29 (August) 296-313.

67. Sullivan, Mary W. (1998), How brand names affect the demand for twin automobiles, Journal of Marketing Research, 35:2; 154-166.

68. (1992), "Brand Extensions: When to Use Them", Management Science, 38 (June), 793-806.

69. (1990), "Measuring Image Spillover in Umbrella Branded Products", Journal of Business, 63, (July), 309-29.

70. Supphellen, Magne (2000), Understanding core brand equity: Guidelines for in-depth elicitation of brand associations, International Journal of Market Research, 42:3, 319-340.

71. Szymanski, David M. and David H. Henard (2001), "Customer Satisfaction: A Meta-Analysis of the Empirical Evidence", Journal of the Academy of Marketing Science, 29:1, 16-35.

72. Tauber, Edward M. (1981), "Brand Franchise Extensions: New Product Benefit from Existing Brand Names", Business Horizons, 24 (2) 36-41.

73. (1985), "Researching Brand Extensions", Journal of Advertising Research, 16 (June/July), 6.

74. (1988), "Brand Leverage: Strategy for Growth in a Cost Controlled World", Journal of Advertising Research, 28 (August/September), 26-30.

75. Tellis, Gerard J. (1988), "The Price Elasticity of Selective Demand: A Meta-Analysis of Econometric Models of Sales", Journal of Marketing Research, 25 (Nov.), 331-341.

76. University of Minnesota Consumer Behavior Seminar (1987), "Affect Generation to Similar and Dissimilar Extensions", Psychology and Marketing, 4 (Fall), 225-237.

77. Volckner, Franziska and Henrik Sattler (2002), "Success factors of Brand Extensions", Conference Proceedings, 31st Annual Conference of the European Marketing Academy, Braga, Portugal.

78. Wells, William D (1993), "Brand Equities, Elephants, And Birds; A Commentary", Brand Equity and Advertising, David A. Aaker and Alexander L. Biel, eds., New Jersey: Lawrence Erlbaum Associates, 345355 .

79. Yoo, Boonghee, Naveen Donthu and Sungho Lee (2000), An examination of selected marketing mix elements and brand equity", Academy of Marketing Science Journal, 28:2, 195-212. 
Table 1

Summary Of Brand Extension Literature

\begin{tabular}{|c|c|c|c|}
\hline $\operatorname{AUTHOR}(\mathbf{S})$ & SUMMARY & MS & CB \\
\hline Aaker \& Joachimsthaler (2000) & Introduces brand architecture tool-brand relationship. & $\mathrm{X}$ & \\
\hline Aaker \& Keller (1990) & Attitude toward extension is higher if consumers perceive "fit" and quality. & & $\mathrm{X}$ \\
\hline Ahluwalia \& Gurhan-Canli (2000) & Accessibility of extension information moderates brand evaluations. & & $\mathrm{X}$ \\
\hline Barone, Miniard \& Romeo (2000) & Positive mood enhances evaluations of extensions similar to favorably evaluated core brand. & & $\mathrm{X}$ \\
\hline Blackston (1995) & Loyalty/willingness to pay premium for brand is a result of successful equity management. & & $\mathrm{X}$ \\
\hline Boad (1999) & Considers ways co-branding achieves variety of business objectives and potential risks. & $\mathrm{X}$ & \\
\hline Bousch \& Loken (1991) & Evaluations of brand extensions are influenced by typicality and brand breadth. & & $\mathrm{X}$ \\
\hline Bridges, Keller \& Sood (2000) & Establishing explanatory links connecting parent brand and extension increases perceived fit. & & $\mathrm{X}$ \\
\hline Broniarczyk \& Alba (1994) & Brand associations may influence brand affect and category similarity with high knowledge. & $\mathrm{X}$ & \\
\hline Buchanan, et al (1999) & Study demonstrates retailer's display decision can negate equity of established brand. & & $\mathrm{X}$ \\
\hline Capron \& Hulland (1999) & Shows highly immobile resources more likely to be redeployed after horizontal acquisition. & $\mathrm{X}$ & \\
\hline Catchings-Castello (2000) & Combining nonverbal and verbal communication using ZMET creates more meaning. & & $\mathrm{X}$ \\
\hline Chakravarti, et al (1990) & Judgments of an extension are best when there are similar features, benefits or usage. & & $\mathrm{X}$ \\
\hline Chaudhuri \& Holbrook (2001) & Brand trust and brand affect combine to determine purchase loyalty and attitudinal loyalty. & & $\mathrm{X}$ \\
\hline Cohen, Jehoshua \& Ho (1997) & Evaluates financial prospects of new line extension concepts. & $\mathrm{X}$ & \\
\hline Cooke \& Ryan (2000) & Posits brand alliances represent symbiosis of reputation endorsement and collaboration & $\mathrm{X}$ & \\
\hline Coulter \& Zaltman (1994) & Introduces the Zaltman Metaphor Elicitation Technique for brand description by consumers. & & $\mathrm{X}$ \\
\hline Crimmins (2000) & Reviews research on brand value from the consumer's perspective. & & $\mathrm{X}$ \\
\hline Dacin \& Brown (1997) & Effects of 2 types of corporate associations on products responses are examined. & & $\mathrm{X}$ \\
\hline Dacin \& Smith (1994) & Examines effects of several brand portfolio characteristics on consumers' evaluations. & $\mathrm{X}$ & \\
\hline Erdem (1998) & Consumers' quality perceptions of brand are affected by brand experience. & & $\mathrm{X}$ \\
\hline Farquhar (1994) & Discusses 4 basic branding strategies for surviving the next century. & & $\mathrm{X}$ \\
\hline Farquhar (2000) & Ownership cycle framework coordinates functions of strong brands and create momentum. & & $\mathrm{X}$ \\
\hline Gurhan-Canli \& Maheswaran (1998) & Brand enhancement occurs with high motivation and incongruent/positive information & & $\mathrm{X}$ \\
\hline Harvey, Rothe \& Lucas (1998) & Examines legal environment and retailers' cross-brand cannibalization opportunity. & $\mathrm{X}$ & \\
\hline Herr, Farquhar \& Fazio (1993) & Consumers' cognitive structure for brand in given product category affects other categories. & & $\mathrm{X}$ \\
\hline Hoxmeier (2000) & Software preannouncements, unfulfilled promises and unreliability affect reputation. & & $\mathrm{X}$ \\
\hline Kardes \& Allen (1991) & Investigates effects of perceived variability on consumers' brand extension inferences. & & $\mathrm{X}$ \\
\hline Keller (1993) & Presents conceptual model of brand equity from perspective of the individual consumer. & & $\mathrm{X}$ \\
\hline Keller (1999) & Discusses effective brand management via reinforcing brands and/or revitalizing brands. & & $\mathrm{X}$ \\
\hline Keller \& Aaker (1992) & Examines factors affecting evaluations of proposed extensions from core. & & $\mathrm{X}$ \\
\hline Kirmani, Sood \& Bridges (1999) & Ownership status moderates effects of stretch direction, brand image, and branding strategy. & & $\mathrm{X}$ \\
\hline
\end{tabular}




\begin{tabular}{|c|c|c|c|}
\hline $\operatorname{AUTHOR}(\mathbf{S})$ & SUMMARY & MS & CB \\
\hline Klink \& Smith (2001) & Identifies traits explaining discrepancy between prior research and marketplace observation. & & $\mathrm{X}$ \\
\hline Kohli \& LaBahn (1997) & Survey indicates brand names critical to success of new product. & & $\mathrm{X}$ \\
\hline Lane (2000) & Challenges view that incongruent extensions are doomed to fail. & & $\mathrm{X}$ \\
\hline Lane \& Jacobson (1995) & Stock market response to extension announcement depends on attitude and familiarity. & $\mathrm{X}$ & \\
\hline Loken \& Roedder John (1993) & Inconsistent extension attribute information affects family brand. & & $\mathrm{X}$ \\
\hline MacInnis, Nakamoto \& Mani (1992) & Compares effects of knowledge structure on product category comparisons. & & $\mathrm{X}$ \\
\hline Meyers-Levy \& Tybout (1989) & Evaluates schema congruity as a basis for product evaluations. & & $\mathrm{X}$ \\
\hline Morrin (1999) & Examines impact of brand extensions on consumer memory for parent brand information. & & $\mathrm{X}$ \\
\hline Morrin \& Jacoby (2000) & Examines impact of brand familiarity and product category similarity on trademark dilution. & & $\mathrm{X}$ \\
\hline Muthukrishnan \& Weitz (1991) & Examines role of product knowledge in consumer evaluation of brand extension. & & $\mathrm{X}$ \\
\hline Oakenfull, et al (2000) & "Hierarchical categorization" allows identification of key elements for brand extension. & & $\mathrm{X}$ \\
\hline Park \& Srinivasan (1994) & Evaluates equity of brand's extension into different but related product category. & & $\mathrm{X}$ \\
\hline Park, Jaworski \& MacInnis (1986) & Normative framework for selecting, implementing and controlling brand image over time. & $\mathrm{X}$ & \\
\hline Park, Jun \& Shocker (1996) & Studies investigating effectiveness of composite brand in brand extension context. & & \\
\hline Park, Milberg \& Lawson (1991) & Feature similarity and brand concept consistency determine success of brand extensions. & & $\mathrm{X}$ \\
\hline Putsis \& Bayus (2001) & Study proposes /empirically estimates descriptive model of firm product line decisions. & $\mathrm{X}$ & \\
\hline Rao, Qu \& Ruekert (1999) & Examines circumstances in which brand names convey unobservable quality information. & & $\mathrm{X}$ \\
\hline Reddy, et al (1994) & Success determinants of brand line extensions & & $\mathrm{X}$ \\
\hline Roedder John, et al (1998) & Indicates flagship product beliefs less vulnerable to dilution than parent brand name beliefs. & & $\mathrm{X}$ \\
\hline Romeo (1991) & Explores effect of negative extension information evaluations and family brand's image. & & $\mathrm{X}$ \\
\hline Samu, Krishnan \& Smith (1999) & Investigates effectiveness of advertising alliance for introducing new brands. & & $\mathrm{X}$ \\
\hline Simonin \& Ruth (1998) & Examines growing/pervasive phenomenon of brand alliances and consumers' attitudes. & & $\mathrm{X}$ \\
\hline Smith \& Park (1992) & Examines effects of brand strategy on new product market share and advertising efficiency. & $\mathrm{X}$ & \\
\hline Sullivan (1998) & Explores effect of brand names on demand by examining used twin automobile price ratios. & & $\mathrm{X}$ \\
\hline Sullivan (1990) & Analyzes positive and negative spillover of extensions & $\mathrm{X}$ & \\
\hline Sullivan (1992) & Examines whether brand extensions should be introduced early or late in product life cycle. & $\mathrm{X}$ & \\
\hline Supphellen (2000) & Discusses characteristics of brand associations from perspective of cognitive psychology. & & $\mathrm{X}$ \\
\hline Tauber $(1981)$ & Distinguishes how brand franchise extensions differ from other opportunities. & $\mathrm{X}$ & \\
\hline Tauber (1988) & 4 trends regarding types of leverage emerged from a sample of 276 brand extensions. & $\mathrm{X}$ & \\
\hline Univ. of Minn. CB Seminar (1987) & Examines affect generation to similar and dissimilar extensions. & & $\mathrm{X}$ \\
\hline Yoo, Donthu \& Lee (2000) & Explores relationships between marketing mix elements and creation of brand equity. & & $\mathrm{X}$ \\
\hline
\end{tabular}

MS = marketing strategy approach

$\mathrm{CB}=$ consumer behavior approach 
Notes 